This is the accepted version of a forthcoming article in the Sage journal, Millennium: Journal of International Studies. (date of acceptance: 10 April 2017)

\title{
Imperial mission, 'scientific' method: an alternative account of the origins of IR
}

\author{
Vineet Thakur (SOAS University of London) \\ Alexander Davis (La Trobe University) \\ Peter Vale (University of Johannesburg)
}

\begin{abstract}
This article offers an alternative account of the origins of academic IR to the conventional Aberystwyth-centered one. Informed by a close reading of the archive, our narrative proposes that the ideas and method of what was to become IR were first developed in South Africa. Here, we suggest how the creation of a racially-ordered state served as a template for the British Commonwealth and later the World State. We draw further on the British dominions' tour of Lionel Curtis, founder of the Royal Institute of International Affairs (RIIA), between September 1909 and March 1911, to indicate how Edwardian anxieties about the future of empire fuelled the missionary zeal of imperial enthusiasts, who placed enormous trust in the 'scientific method' to create a unified empire. This method and the same ideas were to become central features of the new discipline of IR. By highlighting the transnational circulation of these ideas, we also provide an alternative to the nationally-limited revisionist accounts.
\end{abstract}

Keywords: Disciplinary history, Empire, Lionel Curtis, South Africa, race, The Round Table

\section{Introduction}

For almost a Century, International Relations (IR) has held us captive to the lore of an 'epistemological big bang'. ${ }^{1}$ Endlessly repeated in lecture halls, scholarly outputs and textbooks is the view that IR began in 1919 with the founding of the Department of International Politics at what is now called Aberystwyth University in Wales. This natal moment was followed by the establishment of the British (later Royal) Institute of International Affairs (otherwise called,

$1 \quad$ Benjamin de Carvalho, Halvard Leira, John M. Hobson. 2011. 'The Big Bangs of IR: The Myths That Your Teachers Still Tell You about 1648 and 1919.’ Millennium: Journal of International Studies 39 (3): 735-758. 
Chatham House) in London. The conventional account holds that these events occurred in the wake of the horrors of WWI. The new discipline, we are told, was inspired by the belief that the 'scientific study of international politics' would help to avoid future conflicts, and promote global peace.

Recent revisionist interventions on the development of the field have done an excellent job in challenging the Aberystwyth-centered account and its whitewashing of the discipline's racist pasts. $^{2}$ These histories have focused on revealing the eurocentrism of IR theory, ${ }^{3}$ on the role of specific thinkers such as Alfred Zimmern, John Hobson, Gilbert Murray and Leonard Woolf, ${ }^{4}$ considering the role of imperialism in early IR thought, ${ }^{5}$ and on specific national contexts. ${ }^{6}$ Particularly important has been Robert Vitalis' work on the US, which has shown how the discipline grew out of the 'science' of racial development, and was used deep into the Cold War to support imperial interests and the maintenance of global white supremacy.

However, these revisionist histories are also limited by a focus on experiences of individual states, most commonly the US or the UK. The development of IR as a global discipline was surely only possible through a transnational circulation of key ideas such as sovereignty, empire, Commonwealth and, especially, the notion of the 'international'. In these pages, we add two new elements to IR's revisionist historiography.

First, we will show that many of these ideas were developed and sharpened not in imperial power centres, but from the margins. Indeed, South Africa (Johannesburg, in particular) became both the laboratory of such ideas and their first implementation. These ideas were then

$2 \quad$ As an illustrative sample, see: Duncan Bell, 'International relations: the dawn of a historiographical turn?’ British Journal of politics and International Relations 3, no. 1 (2001): 115-126; Brian C. Schmidt, The Political Discourse of Anarchy: A Disciplinary History of International Relations (Albany, NY: State University of New York Press, 1998); Robert Vitalis (2015) White World Order, Black Power Politics: The Birth of American International Relations, (Ithaca and London: Cornell University Press, 2015), John Hobson, The Eurocentric Conception of World Politics: Western International Theory, 1760-2010, Cambridge: Cambridge University Press, 2012, James Cotton, The Australian School of International Relations, Palgrave Macmillan: New York, 2013, David Long and Brian C. Schmidt (eds), Imperialism and Internationalism in the Discipline of International Relations, (Albany, NY: State University of New York Press, 2005).

3 Hobson, Eurocentric Conception.

4 G.K. Peatlin 'Globalism, Hegemonism and British Power: J.A. Hobson and Alfred Zimmern Reconsidered,’ History 89, 3 (2004): 381-398; Jeanne Morefield, Covenants Without Swords: Idealist Liberalism and the Spirit of Empire, (New Jersey: Princeton University Press, 2009).

5 David Long and Brian C. Schmidt (eds), Imperialism and Internationalism in the Discipline of International Relations, (Albany, NY: State University of New York Press, 2005).

6 Vitalis, White World Order and Cotton, Australian School. 
circulated, moulded and formalised through networks of people and institutions across the British Empire. Indeed, IR could not have become a global discipline without these networks spreading its ideas. Second, we argue that the Round Table movement, an empire wide community of imperial enthusiasts founded in Britain in 1909, dispersed these ideas, as it provided the institutional setting and the method for the 'scientific' study of international affairs. A strong belief in the scientific method being the vehicle through which ideas of an imperial international would become a reality was epitomized in the founding, production and dissemination of the Movement's journal, The Round Table.

Interestingly, The Round Table (which remains today an IR journal) started publication in the same year as The Journal of Race Development, which Vitalis has termed the first IR journal. Alfred Zimmern, Lionel Curtis and Philip Kerr, the first IR chair at Aberystwyth, founder of Chatham House, and founding editor of The Round Table respectively, were not only close academic collaborators, but also active participants in the Round Table movement. Furthermore, the instruments of the discipline's 'scientific study' within the British Empire in the inter-war period, IR's academic chairs, journals and institutes, were largely the initiatives of the same episteme. So, not only were most of the newly established IR chairs occupied by the Round Table members, but also the inter-war IR institutes opened in Canada (1928), Australia (1933), South Africa (1934), New Zealand (1934) and India (1936) drew upon the same network. Each was institutionally tied to Chatham House. These institutes, excepting their Indian iteration, were based on Round Table societies founded by Curtis during his Dominion tour, which occupies our attention below. ${ }^{7}$ Moreover in the 1940s, most of them established IR journals, which drew upon Curtis' original methodology and mission in their editorials: the gathering of 'facts' for the bringing about of world peace. ${ }^{8}$

In excavating both the Round Table and its pre-history in South Africa, we also draw attention to another of IR's fables. We are told that E.H. Carr's classic, Twenty Years' Crisis, ${ }^{9}$ first challenged the vain moralism of the 'world peace' narrative of IR at the cusp of the World War Two (WWII), and that the resulting disciplinary narrative was grounded in a 'realist' analysis of

Curtis ‘Dominion Tour Diary’, MS Curtis 142, Bodlean Libraries, Oxford.

8 These journals include the Australian Journal of International Affairs (formerly Australian Outlook), International Journal, Pakistan Horizon, India Quarterly, South African Journal of International Affairs and New Zealand International Review. For editorials which echo Curtis' vision, see: R.J.F. Boyer, 'Foreword', The Australian Outlook, 1, 1 (1947): 4 and R. M. Fowler, 'Foreword: To First Issue of International Journal', International Journal, Vol. 1, No. 1 (Jan., 1946): 5-6.

$9 \quad$ E.H. Carr, The Twenty Years' Crisis -1919-1939: An Introduction to the Study of International Relations, (London: Macmillan (1939) 1946). 
international politics. Revisionists have critiqued Carr's characterisation of writers like Alfred Zimmern, Norman Angell, Woodrow Wilson, Arnold Toynbee, as “idealists”. ${ }^{10}$ But scant attention was paid to the fact that Carr's own understanding of idealism neatly fitted a celebrated text which was published a few months before Carr started writing his acclaimed book.

The text in question was the three volume study, entitled Civitas Dei, ${ }^{11}$ which was written by the founder of Chatham House, Lionel Curtis. Curiously Carr, who was also associated with Chatham House, omits a mention of Curtis and his book in the Twenty Years' Crisis, but Curtis's book can be seen as the (invisible) thesis to Carr's anti-thesis because it unabashedly champions the cause of a World Commonwealth. Curtis and this book loom large in this essay.

Central to our argument is that both Carr and IR's disciplinary history are silent on the notion that the realisation of world peace through a 'World Commonwealth' was modelled on a 'real world' event: the formation of the Union of South Africa in 1910. Its immediate backdrop, the Second Anglo-Boer War had forced the politicians and intellectuals in the four colonies of southern Africa to transfer their individual sovereignties into a union. In South Africa, this task had been promoted by a committed group of young men who successfully used knowledge and the instruments of its propagation (institutions, journals, the formal exchange of ideas) to achieve imperial goals.

But there is another silence in Carr's analysis: the issue of race. While denouncing early ‘theory' for its lack of realism, Carr elevates it to a moral high ground. In doing so, he also sanitises its deep and regressive racism. An understanding of race as 'natural' was common to all political analysis until WWII, ${ }^{12}$ but curiously Carr's (and later IR's) equation of 'idealism' with morality erases race from disciplinary memory.

We argue here that the Round Table was actually based on an earlier effort, called the Closer Union Societies, which was formed in South Africa in 1908. The journal Round Table was modelled on a bilingual South African-based journal The State/Die Staat which was published from 1908-1912. Moreover, the ideas, methods of work, research and propaganda of the Round

10 Peter Wilson, 'The Myth of the First Great Debate,' Review of International Studies 24, 5 (1998): $1-16$.

11 Lionel Curtis, Civitas Dei: The Commonwealth of God, (London: Macmillan, 1938). The US edition was titled The Commonwealth of God.

12 Christian Guelen, 'The Common Grounds of Conflict: Racial Visions of World Order 1880-1940.' In S. Conrad and D. Sachsenmeirer (eds.) Competing Visions of World Order: Global Moments and Movements, 1880s-1930s, (Basingstoke: Palgrave Macmillan, 2007), 69-96. 
Table were pioneered by the same 'thought collective' that had operated in the post-Boer War South Africa, and that had successfully secured a political union. ${ }^{13}$

Through an archival journey into the founding of the Round Table, we trace the emergence of some central ideas and methods through two of its early initiatives: the formation of the Union of South Africa, and Curtis's Dominion tour from September 1909 to March 1911. The latter sought to extend the South African experience into the global arena, its success depended on techniques developed to secure the former. Acting in tandem, they secured a 'scientific method' which was, and continues to be, at the heart of IR's founding identity.

\section{'Curtis's Scheme'}

Our history begins in the first weekend of September 1909 when Lord Anglesey's golf course and cricket pavilion at Plas Newydd in North Wales hosted a series of meetings presided over by Lord Alfred Milner, who had been High Commissioner to South Africa from 1897 to 1905.

The gathering was attended by Lionel Curtis, Robert H Brand and Philip Kerr, three of Milner's protégés during his years in South Africa, and part of a group known as 'Milner's

Kindergarten'; William Marris, a New Zealand-born member of the Indian Civil Service, and G L Craik, both of whom were closely associated with the Milner's Kindergarten; F S Oliver, a businessman who had recently written a biography of Alexander Hamilton, and strongly influenced the members of the Kindergarten; and one Rob Holland, who has not been identified but might have been a Cape Town civil servant who was secretary to Dr Leander Starr Jameson, infamous leader of the 'Jameson Raid' and who was later Prime Minister of the Cape Colony: Lord Lovat, who had raised a regiment to fight in the Anglo-Boer War; Arthur Maitland, Milner's secretary; and Viscounts Howick and Wolmer, son-in-law and son of Lord Selborne, then the incumbent High Commissioner to South Africa. ${ }^{14}$

The meetings discussed, as Milner wrote in his diary, 'Curtis's scheme' ${ }^{15}$ - a set of proposals for reshaping the British Empire, whose naval supremacy and political hegemony was being challenged by Germany, Japan, and the United States. Two of these constituted direct threats to

13 On thought collective, see, Philip Mirowski and Dieter Plehwe (eds), The Road from Mount Pelerin: The Making of the Neoliberal Thought Collective (Cambridge, MA: Harvard University Press, 2009).

14 Deborah Lavin, From Empire to International Commonwealth: A Biography of Lionel Curtis (Oxford: Claredon Press, 1995): 109-110.

15 Alfred Milner, 'Milner’s Diary, 26 August 1909', Alfred Milner Papers, MS. Milner dep. 80, Bodlean Libraries, Oxford. 
Britain: Japan, a rising non-white Empire in the East; and Germany, which was an adversary of Britain in Europe and also in east and southern Africa, was regarded as the antithesis both of British values, and the Anglo-Saxon systems of government.

The United States was seen in somewhat ambiguous terms. It certainly shared a history and a set of values as part of the Anglo-Saxon world, but it offered a successful model of republicanism and rebellion that promised success outside the Imperial family. Consequently, it was seen as a rebellious offspring whose entry into the 'family alliance' of Greater Britain was desirable. ${ }^{16}$ Concurrently, its success was begrudged as it offered an example to the Dominions of the opportunities of separation from the Anglo-Saxon family. These anxieties provoked the necessity to refashion the Empire into an alliance of states that would share responsibility for Imperial defence, and would be less hierarchical and more egalitarian (at least for its white subjects).

Those attending the gathering at Plas Newydd believed, following South Africa's transition to sovereign statehood (then, still a few months away), that the settler colonies in the Empire would all achieve 'sovereignty', a development that would itself require a reconfiguration of the Empire. Without independent powers of decision in respect of domestic foreign policy and defence, however, the Dominions could not really claim to enjoy full sovereignty. At the same time, Britain could not afford the military expenditure that was needed to sustain its Imperial hegemony. So, the Dominions were required to help defend the Empire and Britain had to give them a stronger voice in domestic and foreign matters, and in governing the Empire itself. ${ }^{17}$ Proposals for this approach were encapsulated under the notion of 'Imperial Unity'.

In a key passage in a memorandum recording 'conversations... between a few English and South African friends... during the summer of 1909', Curtis described 'Imperial Unity' as the 'only means of securing the political ideals of the race - real nationality and self-government to those capable of exercising it, and to those which are not, government in the interest of the governed themselves'. ${ }^{18}$ For those gathered at Plas Newydd, then, the notion of Empire was not only about the need to maintain Imperial hegemony, but also about fostering self-government. Given this, they believed the shift towards Imperial Unity was the culmination of the true ideal of the British Empire.

16 Duncan Bell, The Idea of Greater Britain: Empire and the Future of World Order, 1860-1900, (Princeton: Princeton University Press, 2007).

17 'Memorandum of conversation which took place between a few English and South African friends at intervals during the summer of 1909', MS Curtis 156/1, Boldlean Libraries, Oxford. 
Having established their ultimate objective, the group's interest then moved to the issue of how to bring this about. Participants believed that 'Imperial Unity' would not come about on its own. Rather, achieving this would require a dedicated set of 'public men in distant communities [who were] animated by a common purpose', who would be required to work in a unity of method. ${ }^{19}$ If these differed, there would be conflict among the devotees, and the cause of Imperial Unity would fail. Therefore, they had to pursue one general plan simultaneously within the five settler communities: failing this, the danger was that 'the forces available may "lose themselves in aspirations", ${ }^{20}$

But what method would secure this goal?

While this remained largely undecided, a few preliminary steps were taken at the meeting. First, a deputation would be sent to each of the Dominions. Through a 'process of personal selection', in each Dominion, the deputies would carefully select a small group of Imperial enthusiasts. ${ }^{21}$ Once these were nominated, an executive agent would be appointed for each of the groups who would be responsible for carrying out its activities. In order to make this Empire-wide scheme effective, a core group would have to work in London, the imperial centre. In addition, an itinerant delegate would visit the various groups in order to collect, digest and disseminate information.

From this consultation, an Imperial statement setting out 'the alternatives involved, the real problem of disruption, the sacrifices needed to avoid it, and the successive stages through which the ultimate goal is to be sought'. ${ }^{22}$ Once this was issued, its goals would be taken up by all groups as 'a creed to which all have contributed, and all have subscribed'. ${ }^{23}$

Two further things were noted at the meeting. First, the movement should avoid making the Imperial statement public (responding only to 'genuine and responsible queries'). Second, the movement should avoid identification with any political party. ${ }^{24}$ As Milner noted in his diary, all these points came from Curtis, but the 'scheme' had its roots in South Africa. We now turn our attention to these roots, to look at the ways in which IR's original methods and identity were honed by the Kindergarten's efforts to construct a state in South Africa.

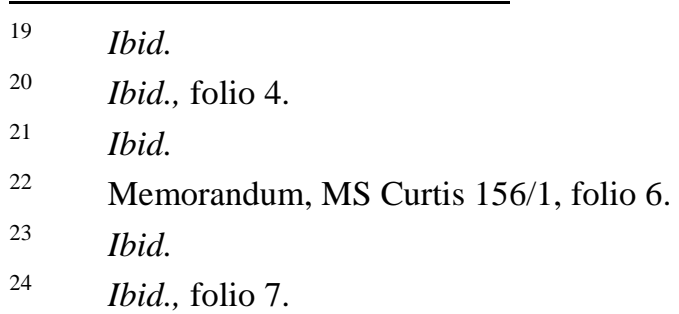




\section{Making the South African state}

The Union of South Africa was established on 31 May, 1910. Eight years earlier, the two defeated Boer Republics, the Transvaal Republic and Orange Free State Republic, had surrendered their sovereignty to the British Empire. Alfred Milner, who was then British High Commissioner, and his 'young men' (as Walter Nimocks called them) played a central role in bringing this about. ${ }^{25}$

Like many of his generation, Milner considered the British Empire to be a moral force for civilization. However, his idea of the Empire differed from the accepted norm. In his farewell speech in Johannesburg in March 1905, he had declared:

The word Empire, the word Imperial, are, in some respects, unfortunate. They suggest domination, ascendance, the rule of a superior state over vassal states... When we, who call ourselves Imperialists, talk about the British Empire, we think of a group of States, all independent in their own local concerns, but all united for the defence of their own common interests and the development of a common civilization; united not in an alliance - for alliances can be made and unmade... but in a permanent organic union. ${ }^{26}$

For Milner, the Empire was a group of white self-governing communities bound by a common 'civilization'. The ultimate goal of the idea of Empire, he argued, could only be a 'permanent organic union', where elements within the organism would gravitate towards each other in a 'natural' way, and that each played a role in sustaining the entity as a whole.

At the end of the Anglo-Boer War, Milner assumed the Governorship of the Transvaal and Orange River Colony. From these commanding heights he embarked on a project of statebuilding in what would become South Africa. The process began with the overhaul of the state's bureaucracy. In the years following the war, he recruited a group of young men -- mainly from New College and Balliol College in Oxford -- who shared his dream of a united southern Africa. Derisively called 'Milner's Kindergarten' (first by William Marriot), the group included Robert Brand, Patrick Duncan, Geoffrey Robinson (later Dawson), Richard Feetham, Dougal O Malcolm, Hugh Wyndham, Lionel Hitchens, F (Peter) Perry, Philip Kerr, John Dove and Lionel Curtis.

\footnotetext{
25 Walter Nimocks, Milner's Young Men: The 'Kindergarten' in Edwardian Imperial Affairs (Durham: Duke University Press, 1968).

26 Alfred Milner, The Nation and the Empire: Being a collection of speeches and addresses, (London: Constable and Company, 1905 [1913]): 90-91.
} 
When Milner left South Africa in 1905, the Kindergarten carried forward his project with the willing assistance of his successor, Lord Selborne. Although the Kindergarten was tethered to Milner's name, its intellectual projects went far beyond Milner and his work in South Africa. ${ }^{27}$

While Milner had provided a broad outline, Curtis and his colleagues fleshed out the details of the unification of the four colonies through a series of intellectual initiatives. These included the establishment, in September 1906, of a closed thought collective called the 'Fortnightly Club'. Here, Milner's Kindergarten met with other devotees of Empire to discuss issues relating to the formation of a united South Africa, and its relations with, and ramifications for, the Imperial project. Its proceedings were recorded in the Fortnightly Club Collection, now archived by the University of the Witwatersrand in Johannesburg.

These papers record discussions on thoughts about sovereign statehood, racial segregation, the immigration of Asians and imperial politics generally. A particular preoccupation of the Club was the absence of an Empire-wide theory of government. The existing British Empire, as Curtis argued in an early presentation to the Fortnightly Club, was the outcome of a series of contingent developments in Canada, Australia, South Africa and India. As a result, the interrelationship between Empire, State and Society, the three constituent features of Imperial community, were blurred. It was unclear what sovereignty might mean for each of the Dominions, or, indeed, what it might look like within the imperial project. Consequently, ideas around political authority within the Empire were fragmented, and the relationship between entities was uncertain. ${ }^{28}$ Simply put, there was a worrying absence of a coherent theory of imperial rule.

For Milner and his acolytes, South Africa was an important case-study in imperial security and politics because it was as a microcosm of the Empire. They argued that just as the British Empire was threatened by other powers, especially Germany, the future of the southern African colonies was threatened by the agitation of its African populations.

How did they arrive at this comparison?

During the Boer War, the other Dominions had sent their forces to southern Africa to fight for

$27 \quad$ For more on this group, see Nimocks, Milner's Young Men, Lavin, Empire to International Commonwealth, Carroll Quigley, The Anglo-American Establishment, (New York: Book 1981); May, 'The Round Table, 1910 -1966', and John Kendle, The Roundtable Movement and Imperial Union (Toronto: University of Toronto Press, 1975). 
the imperial cause. In the same way, the southern African colonies had dispatched troops to suppress the Bambatha Rebellion which had broken out in the colony of Natal in $1905 .{ }^{29}$ This suggested that a common threat to security could unify whites in southern Africa, as well as whites across the Empire. Moreover, the southern African colonies were perhaps the most representative of the racial and immigrant 'problems' of the Empire as a whole. For one, they encapsulated an intra-civilizational European conflict which resembled the Irish question: this was the tense relationship between Boer and Brit in South Africa.

But the country also reflected the Empire-wide 'inter-civilizational' line between Europeans and non-Europeans: here, two 'civilizational' extremes were juxtaposed: the English and the Africans. Added to this social mix was the issue of Asians who occupied a liminal space between these two racial extremes in South Africa as well as within the Empire. As immigrants, the question of their rights as subjects of Empire was being raised most vociferously in South Africa by a recent arrival, Mohandas Gandhi. South Africa became an important political laboratory for the Kindergarten, with South African statehood seen as a precursor of, and a model for, their grand project of creating an 'Organic Union'.

While the Club fleshed these ideas out, Curtis, with the help of other members of the Kindergarten, prepared a missive called the Selborne Memorandum. ${ }^{30}$ In essence, it was a statement about the interdependent and mutually reinforcing relations of the four colonies that gestured towards the formation of a federal state. But a year later, in 1908, the Kindergarten published a two-part volume entitled The Government of South Africa, which set out the case for a unitary government in the country. It was written mostly by Lionel Curtis. ${ }^{31}$

Interestingly, the argument in the book had begun with the assumption that South Africa should become a federation. This idea followed from a reading of Oliver's aforementioned biography of Alexander Hamilton which pointed towards an 'American plan' to create a federal structure, for the ailing British Empire. ${ }^{32}$ But, Curtis noted, that his own 'enquiries into the actual facts' had revealed that a political union was a more desirable option for South Africa. ${ }^{33} \mathrm{He}$ emphasised that 'research' had pulled his own thinking (and that of the Kindergarten) towards

29 The Bambatha Rebellion was a Zulu revolt in Natal over taxation and British rule.

30 Basil Williams (ed.), The Selborne Memorandum: A Review of the Mutual relations of the British South African Colonies in 1907, (Oxford: Oxford University Press, 1925).

$31 \quad$ Nimocks, Milner's Young Men: 97.

32 John Fair, 'F.S. Oliver, Alexander Hamilton and the “American Plan” for resolving Britain’s constitutional crisis, 1903-1921,’ Twentieth Century British History, 10, 1 (1999): 1-26.

33 The Government of South Africa, The Government of South Africa, Volume 1\&2, (South Africa: Central News Agency, 1908): X-xi. 
the Union option, 'in spite of their pre-conceived ideas'. ${ }^{34}$ This sign-posting is crucial in explaining the development of IR's methodology, because Curtis often cited this as an example of 'scientific research', and how objective enquiry had persuaded the Kindergarten to change their minds on important issues. From this point onward, The Government of South Africa served as a methodological primer for all of Curtis's later works, including The Commonwealth of Nations and Civitas Dei . ${ }^{35}$

In 1908, the Kindergarten embarked on two further projects which later played an important role in their evolving 'scientific' method of understanding the world. The first was the establishment of a public association called the Closer Union Societies; second the launching of a journal called The State. The purpose of the former was to propagate for the establishment of a unified South African state within the British Empire. ${ }^{36}$ The latter was the vehicle that promoted the same ideas on behalf of the Closer Union Societies.

Conventional history suggests that politicians like Jan Smuts, John X Merriman and Louis Botha played a bigger role in establishing the Union of South Africa than did the Kindergarten. ${ }^{37}$ However, the Kindergarten understood itself as having a background role in the process. In a moment of self-congratulation, Lord Selborne wrote to Curtis saying:

I am quite sure that had it not been for...(the book)... 'The Government of South Africa', we never should have got such an excellent form of constitution and, although you had many splendid helpers, the main credit for this work must always be yours... Milner's Kindergarten will have more profoundly influenced the history of South Africa than any combination of Afrikanders (sic) has ever done. ${ }^{38}$

It is important to note that the Kindergarten based the legitimacy of their subsequent efforts to develop a theory and practice of thinking about world affairs almost entirely on their activities in South Africa. In other Dominions, a belief took hold about how with '30-40 men went and planted themselves in the different colonies in South Africa' and 'accomplished (the South African) union' through research and propaganda. ${ }^{39}$ The scope of their ideas on these issues evolved from Organic Union in early 1910s to the British Commonwealth in the late 1910s, to

$34 \quad$ Ibid.

35 Lionel Curtis, The Commonwealth of Nations (London: Macmillan: 1916) and Curtis, Civitas Dei.

36 The State, ‘Association of Closer Union Societies’, The State, 1, 1 (1910): 113-116.

37 Leonard Thompson, The Unification of South Africa 1902-1910, Oxford: Clarendon Press, 1960.

38 Lord Selborne to Curtis, 8 Feb 1909, MSS Curtis Reel 1: General correspondence and paper, c. 1880-1909, Boldlean Library, Oxford. SA Atkinson to Lionel Curtis, 10 May 1912, MSS Eng. Hist. 777, f. 68. Emphasis added. 
the World State in the 1930s. When challenged on the worth of these ideas and their evolution, Curtis would refer to South Africa, where the combination of research, knowledge and propaganda had created a new political reality. ${ }^{40}$ With the Union of South Africa guaranteed, Curtis and the Kindergarten turned their attention to the future of the Empire itself. In a letter to Leo Amery in March, 1909, he explained that in South Africa, the Kindergarten had 'acted as an advance party of sappers sent out to build a vital section of the road over which the main force will have to travel later on'. ${ }^{41}$ As with the Selborne Memorandum, his initial challenge was to identify and 'state the Imperial problem'. This was to be done through a well-researched 'memorandum', which would serve as a common reference for all Imperial Union enthusiasts. As Curtis had done in South Africa before writing the Selborne Memorandum, he would visit all the Dominions in preparation of the new document. Once the Imperial Statement had been drafted, it would be shared with like-minded people across the Dominions: they would promote a movement towards an Imperial Union. He also insisted on launching a publication, along the lines of The State, which would circulate their Imperial Union gospel.

To succeed, they had to convince sympathetic people in London, particularly their patriarch and patron, Lord Milner. In July and August 1909, Milner presided over a series of meetings in and around London, attended by F S Oliver, Lord Lovat, Leo Amery, Leander Starr Jameson, and Milner's successor in South Africa, Lord Selborne. ${ }^{42}$ At these gatherings, Curtis, Brand, Kerr and Robinson tried to convince the others of their plans for the future of the Empire. It was these events that led to the weekend retreat at Plas Newydd. As the project took shape, however, the Round Table found themselves divided on how to imagine the future of a racialized world order.

\section{From Organic Union to Commonwealth: debates about race}

Given the green light to proceed at the Plas Newydd gathering, Curtis left England on 17 September 1909 on the Canadian leg of an 18-month tour of the British Dominions. On the four-month tour of North America, he was accompanied by Philip Kerr and William Marris. They returned to England in January 1910. However, Curtis soon left again to visit South

\footnotetext{
40 In 1951, when Curtis was asked how he thought the world state could be achieved and world peace achieved, Curtis turned to the example the Union of South Africa. See, Aysen Dilek Lekon, 'The Interplay of Realism and Idealism in the thought of Lionel Curtis: A Critique of the conception of "First Debate” in International Relations', Unpublished PhD Thesis, London School of Economics and Political Science, (London, 2003): 9. Quoted in Nimocks, Milner's Young Men: 134. Nimocks, Milner's Young Men: 147-148.
} 
Africa, New Zealand and Australia, returning to England in March 1912. ${ }^{43}$

Whilst in Canada, Kerr also spent a month in the United States. This side trip is explained by his deepening interest in the racial question in the American South, which he regularly wrote about in The State. These ideas provide a crucial window on Curtis's scheme, and the racist birth of IR and complement recent work, especially that of Vitalis. The latter has certainly highlighted the fact that American ideas on race were central to early imaginings of the discipline-in-the making. The Kindergarten's musing on these issues suggest that ideas of race and racial hierarchy enjoyed a wide trans-continental circulation.

This understanding is reinforced by the fact that Philip Kerr's interest in segregation was not limited to South Africa; instead, he projected the idea of racial segregation as a template for global relations. ${ }^{44}$ As late as 1916, in the first introductory text to IR, Kerr wrote that the division of mankind on a 'graduated scale' of civility and barbarism was 'one of the most fundamental facts in human history' ${ }^{45}$

Placing the clashes between the Japanese and the Canadians alongside Gandhi's movement for the rights of Indians in South Africa, Kerr was worried that racial violence could become commonplace across the Empire. These fears were sparked by Japan's victory in the RussoJapanese War of 1904-1905. In Canada, Kerr learnt that tensions were brewing between Ottawa and Tokyo over restrictions on immigration from Japan. Characterising Asians as alien elements whose entry into the Dominions must be prevented to preserve the white body politic, he argued that world peace could only be guaranteed if Asians and Europeans were isolated from one another. In praise of segregation, he wrote that 'two races shall never be allowed to intermingle in the same territory in future. South Africa and North America have adopted that policy. It seems likely that the rest of the world will follow suit. ${ }^{46}$

While Kerr feared inter-racial conflict, Curtis and Marris were revising their thoughts on race in the world. Curtis in particular had begun to worry about the 'Indian question' and the scheme for Organic Union. Until this point, Curtis had strongly advocated a segregationist position in opposition to the liberal Darwinist belief that races could be 'civilized' and assimilated. However, his ideas about race changed during the visit to Canada. Years later, in his 1920

\footnotetext{
$43 \quad$ Ibid., 158-178.

$44 \quad$ Philip Kerr, 'The Month’, The State, 2, 12 (1909): 687.

45 Philip Kerr, 'Political relations between advanced and backward peoples' in A. J. Grant et. al. (eds), An Introduction the Study of International Relations, (London, 1916): 168. Ibid.
} 
Letter to the People of India, he recorded his change in thinking. It occurred during an exchange with Marris during a discussion of anarchism in India where the latter expressed the view that British policy in India needed a guiding principle, and the only conceivable one was 'selfgovernment'. In line with this, Britain's 'primary duty' was to extend western education to India, thus preparing Indians to govern themselves. This observation, Curtis confessed, was one of the milestones in his education. ${ }^{47}$

In 1907, Curtis's view had been that the white man's burden was not to drag non-Europeans to civilization, but to design the best form of government for maintaining the race barrier. He believed that self-governing institutions were suitable only for those at the top of the civilizational ladder. Drawing a binary distinction between 'static' and 'progressive' societies, he had argued that all progressive (white) societies had developed institutions of selfgovernment - among these, Britain's were the most advanced. In contrast, the non-western societies, particularly Oriental ones, he regarded as 'static' (Africans only had 'tribes', not even societies, in his view). At the time, Curtis believed that Britain had the responsibility of ruling static societies through a bureaucracy which was autocratic but efficient. ${ }^{48}$

However, his talk with Marris changed his view on these matters. 'It was from that moment that I first began to think of "the Government of each by each, and of all by all" not merely as a principle of western life, but rather of all human life, as the goal to which all human societies must tend. ${ }^{49}$ He went on, 'I began to think of the British Commonwealth as the greatest instrument ever devised for enabling that principle to be realised, not merely for the children of Europe but for all races and hundreds and peoples and tongues'. ${ }^{50}$ From this point forward, Curtis confessed, I 'ceased to speak of the British Empire', using the term 'Commonwealth of Nations' instead. ${ }^{51}$

With this shift, his investigation of the idea of Organic Union could not be completed without turning attention to both India and Egypt, the two dependencies with the strongest claims on self-government. Previously, Organic Union had only included white subjects. In this understanding, India and Egypt, like other the dependencies were to be 'governed in the interest of the governed themselves'. Indeed, a document prepared for the Moot (as Round Table

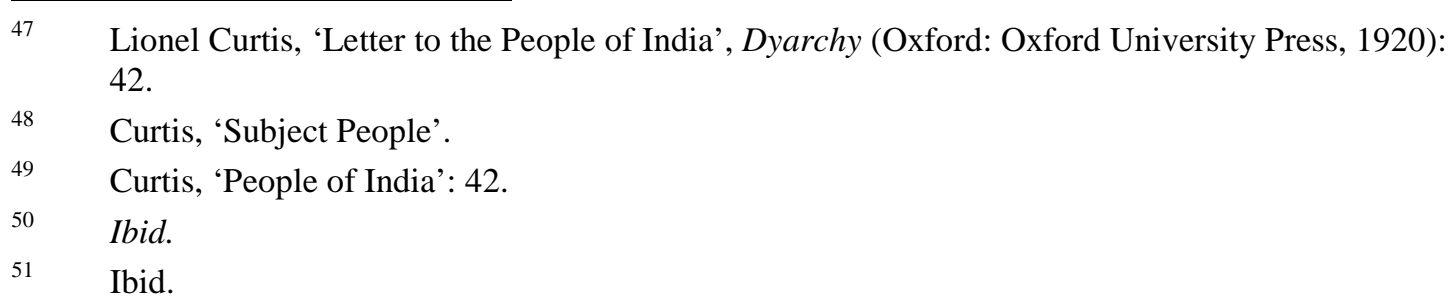


gatherings were called, after the house in Johannesburg where the Fortnightly Club had first met), Leo Amery noted that an 'Organic Union' had to deal with:

...a group of autonomous democratic British communities on subjects of common interest, and the efficient administration and development of a number of dependencies inhabited by populations of every conceivable race, some of them still in the lowest forms of civilisation, and all of them as yet unfit for responsible self-government.

These categories, Curtis argues, 'call[ed] for different methods and for different qualities in the men who are responsible for these methods'. ${ }^{52}$

But in Curtis's new understanding, the self-government of dependencies was integral to the development of British institutions themselves. After the Dominion tour, his discussions with the Moot focused on India's and Egypt's place in their schemes. As Curtis's biographer has pointed out, Organic Union only required the territorial presence of the dependencies in the Empire, but the principle of Commonwealth had to include their peoples as future imperial citizens. Other members of the Moot rejected these suggestions, while Curtis's close associate and friend, Robert Brand, told him: 'I intend that the white man shall always be top dog. ... I am not at all sure that... [your thinking]... is consistent with mutual citizenship in a Commonwealth. ${ }^{53}$

Curtis saw the British Commonwealth as a natural progression from Organic Union, where British dependencies that had advanced far enough up the racial hierarchy could be included in Imperial brotherhood. In 1916, Curtis visited India where he wrote a text on Indian selfgovernment that was crucial to governmental reforms. However, the inclusion of India (and Egypt) in the Imperial scheme was only an affirmation of the neo-racist view that some nonwestern cultures were more teachable than others. ${ }^{54}$ In December 1918, Curtis anonymously published an article in The Round Table entitled 'Windows of Freedom', calling on the League of Nations to delegate the responsibility of governing 'derelict territories' to some 'democratic

\footnotetext{
52 Leo Amery, 'Notes on the Re-organisation of Official Relations between the United Kingdom and the Dominions, and on the possible development of the Conference System', GD40/17/13, folio 55 (1911), Lothian (Philip Kerr) Papers, National Archives of Scotland, Edinburgh.

$53 \quad$ Lavin, Empire to International Commonwealth: 117.

54 On neo-racism, see Etienne Balibar, 'Is There a “Neo-Racism”?', in Etienne Balibar and Immanuel Wallerstein, Race, Nation, Class: Ambiguous Identities, London: Verso,1991 , pp. 1728. On how this neo-racism was deployed in inter-war diplomatic practice, see Vineet Thakur 'Liberal, Liminal and Lost: India's first diplomats and the narrative of foreign policy', The Journal of Imperial and Commonwealth History, Online first: doi.org/10.1080/03086534.2017.1294283, 2017.
} 
power' ${ }^{55}$ Through this, Curtis became influential in formulating the Mandates System: formalizing the liberal racialized world order. It is clear that Curtis was also influenced by the ideas of Philip Kerr and Alfred Zimmern on the issue of Mandates. Jan Smuts, who is often credited as the architect of the Mandates System of the League of Nations, consulted Curtis's article when he researched his own proposals on the Mandate issue. ${ }^{56}$

These issues were more concretely expressed in Curtis's text, Civitas Dei. ${ }^{57}$ In this 1000-page tome, Curtis made a case for a global commonwealth of nations operating on two levels: one comprising western nations and 'civilised' non-white countries like India and Egypt, and the other, the rest of the non-west. For him, notwithstanding his change in thinking, the notion of World Government continued to represent a racialised world order. It was with this goal in mind that the new mode of study was disseminated throughout the empire.

\section{IR Methodology and dissemination}

Besides spreading the idea of 'Organic Union', Curtis’s Dominion tour was a 'fact-finding' mission during which he studied the four countries allowing these experiences to shape both his broader political objectives, and the means for achieving them. It is this encounter, we believe, that sowed the seeds of IR's original method.

One of the lesser known contributions of the Kindergarten, and especially Curtis, was the notion that 'scientific research' should guide both understandings of the changing world and policy recommendations that would shape it. Their approach evinces a narrow, empiricist understanding of knowledge, and which continues to guide IR think-tank research across the world. As with IR itself, Curtis's scheme for a reconfigured Empire was underpinned by a strange, yet absolute, moral certainty, namely that the 'scientific study of international relations' would lead to peace. ${ }^{58}$ But how did IR's founders come to define what the 'scientific study' of international affairs meant?

To address this, we must return to pre-Union South Africa, and to Curtis's Dominion tour. In the course of both, Curtis used a method of study that helped to shape what became the RIIA and its affiliates' 'scientific' method that shortly spread to the Dominions and eventually across

55 Lionel Curtis, (1918) 'Windows of Freedom', The Round Table, 8 (3): 25-26.

$56 \quad$ Lionel Curtis to Eric Walker, 12 March 1931, BC 614, Eric Walker Papers, University of Cape Town Archives.

57 Curtis, Civitas Dei.

58 Stephen King-Hall, Chatham House: A Brief Account of the Origins, Purposes and Methods of the Royal Institute of International Affairs, (London: Royal Institute of International Affairs, 1937). 
the world.

In preparing statements for their projects, the researchers undertook field tours. This first began in South Africa but, as we have noted, continued on a far grander scale during Curtis's tour of the Dominions. During his travels, Curtis would study secondary sources, and conduct extensive interviews with influential and 'knowledgeable' individuals. On the basis of the 'facts' gleaned from these sources, a report would be drafted for circulation among a select group across the Dominions. Following this, wider self-selecting groups would discuss the draft and enter their comments into interleaved copies. These copies would be sent back to Curtis, who would then prepare the next draft. At every iteration, the 'method' involved fieldwork, interviewing, library research, drafting, and an early form of peer review. The final draft was only completed after this long process.

For example, after his interactions with people in Canada in late 1909 and early 1910, Curtis wrote a draft report entitled 'Memoranda on Canada and the British Commonwealth', also called the Green Memorandum. ${ }^{59}$ He finished this draft in South Africa between March and May 1911, and sent it to London, where Kerr made copies to be delivered to Curtis when he reached New Zealand. Curtis distributed these to people in New Zealand, Australia, Canada and South Africa. He drew on the resulting comments (from about 200 such Round Table members) in drafting his Imperial Statement, which was finally released in 1914. This closed transnational process enabled a male-dominated, all-white thought collective to construct a new imperial vision of the world.

Curtis emphasised the 'scientific nature' of this self-enclosed method and sought to cloak the work under the legitimacy of scholarship. In two different memorandums, one written at the end of his trip to New Zealand and the other after leaving Canada in early 1911, he set out the background of the Kindergarten's approach to these issues in South Africa, and discussed the importance of the method in achieving its goals. In all his writings, he claimed to be applying 'the methods of scientific study to politics'. ${ }^{60}$

Even in personal conversations with potential participants, Curtis emphasised the objectivity of his work. ${ }^{61}$ In a letter to Kerr, he wrote of his difficulties in the Dominions to prove that he was not a propagandist:

59 See MS Curtis 156/5, Lionel Curtis Papers, Bodlean Library, Oxford.

$60 \quad$ Nimocks, Milner's Young Men: 165.

$61 \quad$ Ibid. 
The only way I can meet this is to show them the books we produced in South Africa, and to show them then how again and again, as the results of study, we had to discard ideas which we had long held... our whole experience in South Africa has taught us there, that if we sit down to get at the facts and to review them on their merits, we are likely, before we have done, to be brought to conclusions which we little anticipated. ${ }^{62}$

The 'scientific study' of political issues, which would become the 'scientific study of international relations', was driven by several considerations which need to be underscored.

Firstly, as Curtis frequently made clear, there was the emphasis on the 'objective' nature of study which would make others less apprehensive about the overall projects. Given this insistence, the assertion of objectivity should not be uncritically accepted. As we have shown, the ideas operated within racial discourses, and were influenced by the group's goals for the empire. Moreover, the closed epistemic community within which they worked makes plain that the process was far from open.

Secondly, the desired quest for rigour was judged as the best way of ascertaining 'the facts' which would establish the 'truth'. The latter would emerge once the 'facts' had been written down and 'tested by the criticism of men like themselves in all the countries concerned' ${ }^{63}$ Once this truth was revealed, Curtis would begin to do the 'missionary work with real effect'. ${ }^{64}$ As he once put it, 'until I have got a doctrine I can preach, I am conscious of being utterly paralysed so far as influencing the current course of affairs is concerned'. ${ }^{65}$ (It was no surprise then, that he quickly earned the moniker of the 'Prophet' within the militantly missionary Round Table movement.)

Thirdly, the attention to method points to a significant but understudied aspect of early IR: the purported cognitive link between knowledge and reality. The Kindergarten's work in South Africa and the Round Table's work in the Dominions reflected a strong belief that knowledge created reality. This understanding was rooted in the $19^{\text {th }}$-Century British tradition of 'knowing', primarily reflected in (and influenced by) Herbert Spencer's belief that human nature was constantly evolving, and that human history reflected the eternal march of progress. In this understanding, the purpose of science was to empirically establish this history of

\footnotetext{
62 Curtis to Kerr, 21 July 1910, Lothian Papers, GD40/17/1, folio 65.

63 'Curtis to Oliver', folio 148.

64 'Curtis to Oliver’, 15-16 August 1910, Lothian Papers, GD40/17/12, folio 149.

65 'Curtis to Oliver', folio 148.This statement also prefigures the increasingly Christian leanings of their academic writings in the 1920s and 30s. See, Curtis, Civitas Dei.
} 
progress, and authenticate its telos.

Once this was done, human agency was required for propaganda purposes only. Kerr was confident, as he wrote to Curtis during the Dominion tour, that once the truth had been revealed through the Imperial Statement, it would then only need a few publicly spirited 'men' in each Dominion 'to shout "harooh" (sic) in a spontaneous manner' to create a movement for the end goal, the creation of an Imperial Union. ${ }^{6}$

In 1919, when the RIIA was established, the inaugural memorandum, prepared by Curtis, referred to the crucial link between historical progress, knowledge and reality. ${ }^{67}$ Aside from underscoring this philosophy of 'scientific' study, perhaps the most crucial direct outcome of the Dominion tour was the founding of the journal The Round Table, which showcased 'scientific' research in imperial, and international, politics and carried policy recommendations.

The idea of The Round Table emerged in a meeting between Curtis, Marris and the Canadian journalist John Willison in Toronto. The original plan was to establish magazines, modelled on The State which had been published in South Africa, in each of the Dominions. However, Willison argued that there had to be an organ for communication among all the Dominions. ${ }^{68}$ Curtis hoped that, besides connecting people across the Dominions, the journal could also broadcast information about Dominions to each other, in the same manner in which The State had done in South Africa. To achieve this, each edition of the journal would carry articles from different parts of the Empire. Faced with these 'facts', people would discover commonality, and better appreciate why Imperial Union was necessary. The public face of the journal would also enable the Round Table to dispel the impression that it was a secret society, while garnering supporters across the Dominions.

On 25 February 1910, a plan for a common journal was adopted by the Moot in London. A committee was formed to guide its affairs, comprising Brand, Oliver, Robinson, Kerr (editor) and Peterson (sub-editor). ${ }^{69}$ Replicating their South African roles in the imperial project, Curtis was to tour the various parts of the Empire, and Kerr to manage the magazine from a central office. Soon, however, the two differed over the nature and purpose of the journal. Kerr saw the London editorial office as a functional and ideological nerve centre, and assumed that The

$66 \quad$ Kerr to Curtis, 31 August 1910, Lothian Papers, GD40/17/2, folio 94.

67 Lionel Curtis and W.H. Shepherdson, 'Memorandum', Folder: 2(1) (Royal Institute of International Affairs Library, London, 1919).

68 Curtis to Kerr, 21 July 1910, Lothian Papers, GD40/17/1, folio 61.

69 For a list of original Moot members and the magazine committee, see, MS Curtis 776, folio 149. 
Round Table would follow the same model as The State.

Curtis disagreed with this notion. ${ }^{70}$ In his view, the primary purpose of The Round Table was to collect and disseminate information about the Dominions and the Empire. The propagation of policy would compromise the political neutrality of the journal, and make prospective associates in the Dominions apprehensive about the project. It would look as though London was intent to remain the Imperial centre, and the Dominions were only to serve as appendages to an already settled system.

In Kerr's formulation, the articles for inclusion in the journal were to be written in London, or by people selected by the editorial office, with the Dominions only supplying the information. For the first issue, Kerr had asked Willison in Canada and F Peter Perry in South Africa to contribute. Curtis, however, argued that this would create an unnecessary chain of communication between London and the Dominions, taking away initiative away from the Dominions. He insisted that articles be written by people in the Dominions, and that the authors should also be suggested by local groups. Furthermore, every quarter, an article had to be written by persons from different groups within the Dominion. ${ }^{71}$ Were an article on South Africa in the first issue to be written from the Cape, the next one had to be written by someone from Transvaal. For the journal to succeed, the Dominions had to feel ownership of the ideas. ${ }^{72}$

For his part, Kerr believed the journal would be read by 'a great majority of men (sic) of real influence in politics, journalism, business, etc', and that efforts were underway to inculcate a readership among the 'people who count "in order that from the outset it may reach a large number of readers." ${ }^{73}$ In contrast, Curtis argued that the journal should be read by select people who were appreciative of their project. Curtis warned that aiming for high circulation would lead people to regard it as 'an ambitious journalistic venture and not the journal to circulate between kindred societies or earnest laborious students in search of the truth'. Such diversions might imbue the project 'with an atmosphere of political conspiracy, and give the very impression which would at once be fatal' ${ }^{74}$ The spectre of The State loomed over this particular part of the exchange between Curtis and Kerr because that journal had by now become more of a popular magazine rather than one with a focus on statehood.

\footnotetext{
Memorandum, 18 May 1910, MS Curtis 776, folio 64-72.

Curtis to Kerr, 21 July 1910, Lothian Papers, GD40/17/1, folio 79-80.

Ibid., folio. 70 .

Ibid., folio 67.

Ibid., folio 68 .
} 
Funded by Abe Bailey (who also funded The State in its initial year), The Round Table could afford to restrict its circulation to 200-500 people in each of the Dominions. ${ }^{75}$ The first volume of The Round Table appeared in November 1910, in the middle of Curtis's Dominion tour. By then, Kerr had agreed to all of Curtis's suggestions.

Interestingly, India had been included in its contents, with Marris arguing that 'the educated and highly intelligent Indian' might be able to govern themselves at some far-off point, but also praising the more generous and kinder approach to government the British had begun to take. ${ }^{76}$ The introductory essay argued for British unity, and stated that the journal's goal was to dispel the ignorance each of the Dominions had for one another in order to bring them closer together. ${ }^{77}$ This optimistic goal was, however, tempered as the following suggests:

The founders of The Round Table have an uneasy sense that times are changing, and that the methods of yesterday will not serve in the competition of to-morrow. They feel that if the various communities of the Empire have common interests, they are singularly badly equipped to pursue them. ${ }^{78}$

But it believed that the journal '[would] serve its purpose if it contributes to the better understanding of the problems of the Empire and to their solution, and if no one ever raises the charge against it that it has distorted the truth for its own ends' ${ }^{79}$

And so, achieving Imperial unity was to be a natural process: if imperial truths were gathered, the Empire could be united simply by disseminating them.

\section{Conclusion}

In order to end, we need to return to what still passes for the formal beginning of IR. The Aberystwyth account of the origins of IR conceals more than it reveals. This messianic narrative about IR's 'birth', rising from the ashes of war to bring peace to the world, has, almost for a century now, linked IR's identity to world peace while conveniently erasing its racial and imperial origins. Where the Aberystwyth account of the discipline's origins sees the creation of

\footnotetext{
75 Abe Bailey was a friend of Cecil John Rhodes, whom he considered his mentor. He financed most of the Imperial initiatives of the Kindergarten not just in South Africa but also in London. Later, he also provided funds for establishing the RIIA and arranged for an annual grant to the RIIA in his will.

76 Anon, 'India and the English', The Round Table, 1, 1 (1910): 43.

77 The Round Table, 'The Round Table': 1-6.

78 Ibid., 3.

79 Ibid., 1.
} 
'world peace', our work sees an effort to permanently establish an empire organised, like South Africa, around racial difference.

The centenary of the discipline's founding is a reminder that the (archival) content, (transnational) context and (historical) claims of IR founding history are still too narrow. Deep critical excavations of the politics, sociology and interest of the pre-disciplinary roots suggest different beginnings to the heroic claims which surround the Aberystwyth story. Both the South African story and the Dominion tour which we have traced on these pages are crucial precursors to 'knowing' IR and its modes of 'knowing'.

There is, however, a more deep-seated reason why the disciplinary origins of IR need to be interrogated - and continuously so.

IR has long hinged itself on Martin Wight's claim of the international being the zone of exception. ${ }^{80}$ As calls for decolonising the discipline grow, IR's centre has used this logic of insularity from the everyday to foreclose debates about its theoretical and empirical agenda. Decolonising IR would thus first require stripping the discipline of its historical certainty, and challenging the foundational assumptions of what it means to do IR.

Critically considering IR's pasts would tell us more about its conscious blinkers built through theory. When idealism, for instance, is stripped of its historical abstraction and moral elevation, it becomes less of a theory and more of a practice for imperial stretch. Increasingly we will understand that the historical antecedent to the 'international' is not 'anarchy', as the discipline encourages us to believe, but 'Empire’ structured around the essentialist idea of race.

80 Martin Wight, 'Why is there no International theory?’, International Relations, 2 (1), 1960: 35-48. 